\section{Frequency of islet autoantibodies in relatives of patients with Type II diabetes or gestational diabetes}

Dear Sir,

Despite differences in aetiology and genetic background several studies have suggested an association between Type I (insulin-dependent) and Type II (non-insulin-dependent) diabetes mellitus and have reported an increased risk of developing Type I diabetes for subjects having a parent with Type II diabetes [1-3]. To address whether Type I diabetes-associated islet autoimmunity is also frequent in relatives of patients with Type II diabetes and to clarify whether it could be useful to screen for Type I diabetes-associated autoimmunity in descendants of Type II diabetic patients, we measured autoantibodies to insulin (IAA), glutamic acid decarboxylase (GADA), the protein tyrosine phosphatase IA-2 (IA2A) and islet cells (ICA $[4,5]$ ) in sera from 737 offspring or grandchildren of patients with Type II or gestational diabetes (median screening age 6.0 years, range 1 to 30 years, 340 female). These included 142 offspring and 190 grandchildren of probands with Type II diabetes and 405 offspring from women with gestational diabetes. Diabetes treatment in patients with Type II diabetes consisted of diet in 17 , oral agents in 85 , insulin in 71 patients and was not specified in the remainder. Of probands with gestational diabetes (GDM), 103 were treated with insulin during pregnancy and at the time of offspring screening, 75 had developed diabetes postpartum. The distribution of antibody titers in offspring and grandchildren of patients with Type II or gestational diabetes was similar to that found in control cohorts and in antibody negative relatives of patients with Type I diabetes by Q-Q plot and histogram $[5,6]$. Of the relatives six $(1.5 \%)$ had islet antibody titers outside the normal distribution and above the previously determined 99th centile of antibody titers in our control group (Table 1) [4, 6]. Antibody positivity was confirmed in follow-up samples 0.1 to 6.7 years after the first screening in three of six relatives and one relative had raised IAA in two consecutive samples but became negative on further follow-up. There were three relatives who had HLA DR3, $D Q B 1 * 0201$ or $D R 4, D Q B 1 * 0302$ haplotypes associated with Type I diabetes and the one relative who had both, $D R 3$ and $D R 4$, developed Type I diabetes at the age of 6 years. Oral glucose tolerance tests were normal in the remaining five. The islet autoantibody prevalence of $0 \%(0 / 142 ; 95 \%$ CI $0-3)$ in offspring and $0.5 \%(1 / 190 ; 95 \%$ CI $0-3)$ in grandchildren of patients with Type II diabetes and of $1.2 \%(5 / 405$; $95 \%$ CI $0-3$ ) in offspring of mothers with gestational diabetes is similar to that reported for children from a general population [7] and signifi- cantly lower $\left(p<10^{-5}\right)$ than that found in relatives of patients with Type I diabetes [5, 8]. We conclude that Type II diabetes in Germany is not associated with an increased risk for islet autoimmunity in descendants and that screening for markers of Type I diabetes in Type II families will have a similar cost-benefit ratio to that of screening in the general population and is therefore warranted only in the context of research or intervention trials aiming at studying or preventing the natural course of the Type I diabetes in non-familial cases.

Yours sincerely,

H.E. Naserke, M. Schenker, A.-G. Ziegler

Acknowledgements. This study was supported by a research grant from Hoechst Marion Roussel.

\section{References}

1. Wagener DK, Sachs JM, La Porte RE, MacGregor JM (1987) The Pittsburgh study of insulin-dependent diabetes mellitus. Diabetes 35: 93-99

2. Dahlquist G, Blom L, Tuvemo T, Nyström L, Sandström A, Wall S (1989) The Swedish childhood diabetes study - results from a nine year case register and a one year case-referent study indicating that type 1 diabetes mellitus is associated with both type 2 diabetes mellitus and autoimmune disorders. Diabetologia 32: 2-6

3. Cederholm J, Wibell L (1991) Familial influence on type 1 (insulin-dependent) diabetes mellitus by relatives with either insulin-treated or type 2 (non-insulin-dependent) diabetes mellitus. Diabetes Res 18: 109-113

4. Naserke HE, Dozio N, Ziegler AG, Bonifacio E (1998) Comparison of a novel micro-assay for insulin autoantibodies with the conventional radiobinding assay. Diabetologia 41: 681-683

5. Ziegler AG, Hummel M, Schenker M, Bonifacio E (1999) Autoantibody appearance for development of childhood diabetes in offspring of parents with type 1 diabetes. The 2-year analysis of the German BABYDIAB study. Diabetes 48: 460-468

6. Roll U, Christie MR, Füchtenbusch M, Payton MA, Hawkes CJ, Ziegler AG (1996) Perinatal autoimmunity in offspring of diabetic parents. The German multicenter BABYDIAB study: detection of humoral immune response to islet antigens in early childhood. Diabetes 45: 967-973

7. Strebelow M, Schlosser M, Ziegler B, Rjasanowski I, Ziegler M (1999) Karlsburg Type 1 diabetes risk study of a general population: frequencies and interactions of the four major Type I diabetes-associated autoantibodies studies in 9419 schoolchildren. Diabetologia 42: 611-670

8. Dittler J, Seidel D, Schenker M, Ziegler AG (1998) GADIA2-combi determination as first line screening for improved prediction of type 1 diabetes in relatives. Diabetes 47: 592-597

Table 1. Relatives with raised islet autoantibodies from 737 patients with Type II diabetes or gestational diabetes

\begin{tabular}{|c|c|c|c|c|c|c|c|c|}
\hline \multicolumn{4}{|l|}{ Proband } & \multicolumn{5}{|l|}{ Relative } \\
\hline Proband $^{\mathrm{a}}$ & $\begin{array}{l}\text { Current } \\
\text { therapy }\end{array}$ & $\begin{array}{l}\text { Antibody } \\
\text { status }\end{array}$ & BMI & $\begin{array}{l}\text { Screening } \\
\text { age (year) }\end{array}$ & $\begin{array}{l}\text { Antibody } \\
\text { status }^{c}\end{array}$ & $\begin{array}{l}\text { Age at last } \\
\text { follow-up } \\
\text { (year) }\end{array}$ & HLA DR & HLA-DQB1 \\
\hline grandmother & oral agents & n.a. & n.a. & 28.2 & IAA (9.3U) & 29.7 & 11,15 & 0301,0602 \\
\hline mother GDM-B & none $\mathrm{b}^{\mathrm{b}}$ & negative & 32.8 & 1.1 & IAA $(5.3 U)^{d}$ & 6.8 & 01,11 & 0501,0301 \\
\hline mother GDM-B & insulin & negative & 27.3 & 3.2 & GADA (26U) & 3.5 & 01,4 & 0501,0302 \\
\hline mother GDM-B & insulin & GADA & 31.5 & 6.7 & GADA (108U), & & & \\
\hline \multirow[t]{2}{*}{ mother GDM-A } & none & negative & 26.3 & 3.0 & IAA (23U), GADA & & & \\
\hline & & & & & $\begin{array}{l}(112 U), \\
\text { IA2A (39U), ICA } \\
\text { (40JDFU) }\end{array}$ & 6.0 DM & 03,0401 & 02,0302 \\
\hline
\end{tabular}

a GDM-A: treated with diet during pregnancy, GDM-B treated with insulin during pregnancy, ${ }^{\mathrm{b}}$ none: no diabetes postpartum; ${ }^{c}$ arbitarily defined units; threshold for positivity $\left(99^{\text {th }}\right.$ centile of control subjects) corresponds to $4 \mathrm{U}$ for IAA, $13 \mathrm{U}$ for GADA, 5 U for IA2A, and 5 Juvenile Diabetes Foundation units (JDFU) for ICA (ref. 4,6); ${ }^{\text {d }}$ transient positive; n. a. = not available 